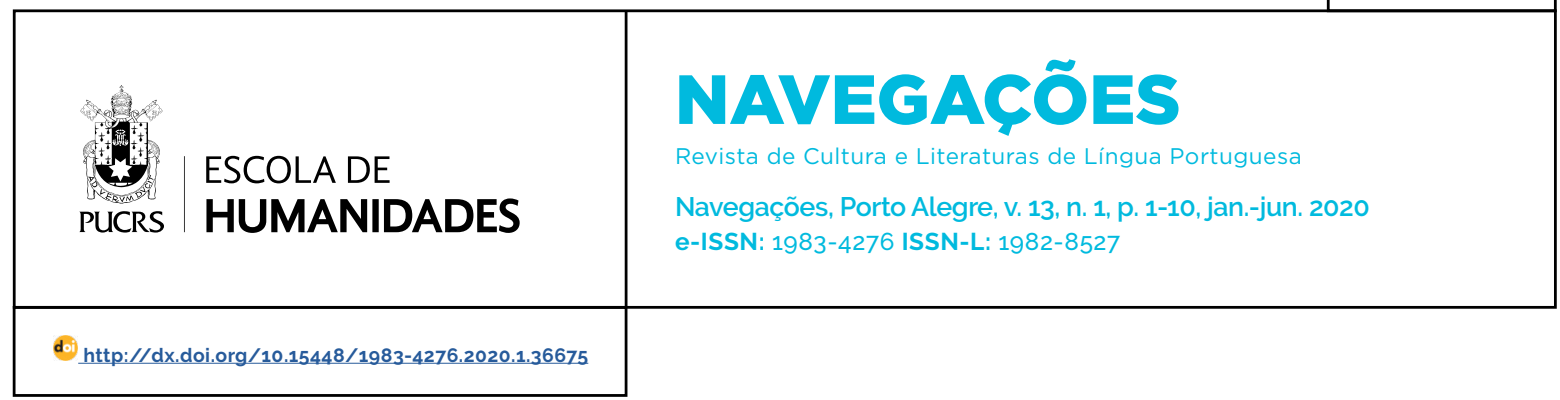

SEÇÃO: DOSSIÊ

\title{
Imagens da mulher chinesa na obra A China fica ao lado de Maria Ondina Braga ${ }^{1}$
}

\author{
Images of the chinese woman in the work A China fica ao lado of Maria Ondina Braga
}

\section{Ming Xin ${ }^{2}$ \\ orcid.org/0000-0001-7576-0117 danielaming918@gmail.com}

Recebido em: 9 jan. 2020. Aprovado em: 23 mar. 2020 Publicado em: 10 ago. 2020.
Resumo: Este artigo tenciona apresentar uma análise das figurações femininas chinesas, do estatuto familiar e social da mulher e da sua luta pela emancipação sobretudo em Macau. Maria Ondina Braga, que viveu nesse território há anos, configurou na sua obra A China fica ao lado imagens de mulheres chinesas. A obra permite-nos olhar para uma evolução da importância da presença feminina das décadas 1940 a 1960 do século XX. Atendendo aos pressupostos teóricos de Jean-Marc Moura, Álvaro Manuel Machado e Daniel-Henri Pageaux, no âmbito da imagologia, analisaremos o modo como a obra assume enquanto plataforma de construção de imagens das mulheres chinesas em Macau. Discutiremos, se no seio de determinado imaginário social, a imagem se pode ou não se converter em estereótipo. Reflectiremos que autoimagem se transmite nesta obra. Quanto à situação das mulheres, será também trabalhado de acordo com as perspectivas enunciadas por Simone de Beauvoir.

Palavras-chave: Imagem. Mulher chinesa. Macau. O Outro.

Abstract: This article intends to present an analysis of Chinese female figures, the family and social status of women and their fight for emancipation, especially in Macao. Maria Ondina Braga, who lived in this territory for years, set up in her work China Stays next to images of Chinese women. The work allows us to look at an evolution of the importance of female presence from the 40 to 60 centuries of the 20th century. Given the theoretical assumptions of Jean-Marc Moura, Alvaro Manuel Machado and Daniel-Henri Pageaux, within the framework of imagology, we will examine how the work assume $s$ as a platform for the construction of images of Chinese women in Macao. We will discuss, within a certain social imagination, whether or not the image can become a stereotype. We will reflect that self-image is transmitted in this work. As for the situation of women, it will also be worked out in accordance with the prospects set out by Simon de Beauvoir. Keywords: Image. Chinese woman. Macao. The Otherness.

\section{Introdução}

Maria Ondina Braga, escritora e tradutora portuguesa, permaneceu em Macau entre 1961 e 1965, onde trabalhou como docente de português e inglês no Colégio Santa Rosa de Lima e, posteriormente, em 1982, rumou a Pequim como leitora de português no Instituto de Línguas Estrangeiras de Pequim. Por sua permanência maior no espaço geográfico do Extremo Oriente, e com uma obra repartida em conto, novela romance e crónica, Maria Ondina Braga é hoje um nome desaparecido na literatura portuguesa contemporânea. 
Com obras como A China fica ao lado, Nocturno em Macau ou Angústia em Pequim, Maria Ondina Braga põe fim à longa viagem de descoberta da China começada por Fernão Mendes Pinto. No prefácio de A China fica ao lado, escreve-se as seguintes palavras:

Quatro séculos depois de Fernão Mendes Pinto, uma escritora de voz singular descobre a China milenária, a sua sabedoria, as suas tradições, os seus mitos. Encontra-a num lugar de convergência, Macau, onde se debatem e combinam duas almas colectivas, dramatizando extensa galeria humana: velhas de pés atados, médicos de práticas escusas, vendedores de produtos exóticos, adivinhos, refugiados, mulheres sem rumo - figuras entre o real e o sonho, inquietas, trágicas inesqueciveis (1968, p. iv). ${ }^{3}$

Na sua experiência de viagem, Maria Ondina Braga coloca, como personagens principais nas suas obras, quer sejam os contos de $A$ China fica ao lado, quer sejam os romances ou as novelas como Nocturno em Macau, mulheres guardadas no seu viver angustiado e solitário. Nessa consequência, criou várias personagens femininas de diferentes tipos, que apresentaremos a seguir, em uma análise das imagens dessas mulheres chinesas.

A China fica ao lado é um livro de contos escrito por Maria Ondina Braga, em Macau, no ano de 1968. As histórias são associadas às suas ricas experiências da vida em Macau no início da década de sessenta do século XX. O contexto histórico e social da sociedade de Macau em que foi criada a obra $A$ China fica ao lado era o periodo após a Segunda Guerra Sino-Japonesa. Naquela época, as guerras na China continental levaram à entrada de muitos imigrantes e refugiados em Macau, cidade nesse tempo governada pela autoridade portuguesa.

A China fica ao lado tem como tema unificador a exploração da cultura chinesa de Macau, com a maioria das histórias sobre pessoas da camada social mais baixa, como mulher idosa de pés atados, curandeiro, antiquário, adivinho, mulher sem direção etc. As personagens variam entre o sonho e a realidade, inquietas tristes, estranhas e fascinantes. Entretanto, há mais um Eu nos contos que se encontram com eles.

A identidade e a saida das mulheres, na obra $A$ China fica ao lado, são diferentes, o que reflete a rica conotação dessa obra de Maria Ondina Braga a partir de diferentes aspectos. Mas, após uma análise detalhada das personagens femininas, podemos descobrir que essas apresentam características tipológicas sob a narrativa da autora. Então, no que respeita às imagens das mulheres chinesas nesse livro, podem ser divididas em seis tipos.

Atendendo aos pressupostos teóricos transmitidos por Jean-Marc Moura, Álvaro Manuel Machado e Daniel-Henri Pageaux, no âmbito da imagologia, analisaremos o modo como as duas obras as assumem enquanto plataforma de construção de imagens das mulheres chinesas em Macau. Discutiremos, no seio de determinado imaginário social, se a imagem pode ou não se converter em estereótipo. E, reflectiremos, que a autoimagem se transmite nestas duas obras. Por outro lado, no que diz respeito à situação das mulheres, será também trabalhado de acordo com as perspectivas enunciadas por Simone de Beauvoir. Para tal, apresentaremos primeiro a evolução das imagens da China e dos chineses no contexto Ocidental; e, depois, abordaremos uma classificação e uma análise detalhada das diferentes mulheres chinesas configuradas nas duas obras de autoras da língua portuguesa.

\section{Mulher "vivendo" na sociedade feudal chinesa}

Maria Ondina Braga criou uma imagem da mulher chinesa que vivia na China contemporânea, mas os seus pensamentos ainda estavam na sociedade feudal chinesa. Os representantes são a avó do conto "A China fica ao lado" e a avó do conto "Fong Song". As duas mulheres, mesmo que vivessem na terra do exilio, não se integraram à presente vida. Elas ainda tinham dois aspectos notáveis em comum, isto é, ambas tinham tido seus pés enfaixados quando criança e eram descendentes de família nobre. 
Em "A China fica ao lado", no conto que abre a coletânea com o mesmo título, relata-se a história de uma menina, descendente de uma familia ilustre, exilada da China continental. Foi sobreviver em Macau com o único familiar, a avó, alojando-se no pagode, em condições instáveis. A história aconteceu no consultório do doutor Yu, pessoa que também era chinês e exilado da China continental e conheceu a sua familia. A menina dirigiu-se ao consultório para fazer um aborto, uma vez que não quis dar à luz um filho fora da lei, tipo de filho com quem também a avó se descontentou.

No que se refere à questão de mulher e filho, a avó tomou uma atitude tipicamente conservadora, como demonstra:

A avó nunca compreenderia. Mulher a ter filhos sozinha só a mãe da humanidade no confucionismo. A avó que dera à luz, na luxuosa maternidade do doutor Yu, com baixela de prata, filhos legitimos, desejados, bem-vindos, de primeira esposa de casa nobre. Esposa ou concubina era o que ela conhecia. Tinha de haver senhor, macho responsável, pai a apresentar núpcias, leito conjugal (BRAGA, 1991, p. 11)

Assim, através da visão cultural representada pela figura da avó, vemos que ela é uma mulher chinesa, tradicional e conservadora. Maria Ondina Braga retratou, nesse conto, uma mulher que viveu na época da China antiga e estava profundamente vinculada à tradição. Ao mesmo tempo, revelou a sua mentalidade servil na sociedade patriarcal tradicional, uma escravidão ligada aos homens.

Então, surge uma questão de género nesse conto. Quanto às diferenças entre homem e mulher, Aristóteles (384 a.C.-322 a. C), um filósofo grego, aluno de Platão e professor de Alexandre, o Grande, acreditava que as mulheres eram inferiores aos homens, como demonstrou na sua obra Politics (1254b, p. 13-14): "no que diz respeito aos sexos, o macho é por natureza superior e a fêmea inferior, o dominante masculino e o sujeito feminino". Para
Aristóteles, "a coragem de homem é mostrada no comando, enquanto a de mulher em obediência" (ARISTOTELES, 1254b, p. 13-14, tradução nossa). ${ }^{4}$

De facto, a perspectiva patriarcada também era historicamente desenvolvida na China. No importante clássico confucionista O livro das mutações, em chinês Yi Jing (também conhecido como / Ching)5, já começou a aparecer a ideia de patriarca e a definição do estatuto social subalterno das mulheres. O livro das mutações definiu as mulheres como força yin e os homens como força yang. As duas forças se complementam, mas não de forma equitativa, na medida em que aos homens cabia uma posição superior, ao passo que às mulheres seria reservado um estatuto inferior. Partindo desse pressuposto, as mulheres deveriam se submeter aos poderes políticos, do clã e do marido.

Por outro lado, pode-se ver nesse conto que a protagonista se sentiu envergonhada por ter um filho fora da lei, gerado à margem. Talvez esse fruto fosse de um ato de violação, da qual se quisesse se libertar. Neste caso, como refere Dora Nunes Gago:

Ao adoptar esta perspectiva tão caracte-
ristica da cultura estrangeira de "acolhi-
mento", notamos uma tentativa de apro-
ximação do "outro", na medida em que
se procura contemplar o mundo através
da sua óptica cultural (GAGO, 2017, p.12).

Através da reflexão interna da protagonista, mostra-se que os pés atados da avó eram a razão pela qual ela chorava, pois "Tudo se resumia nessa noite. Toda a dor reflectia essa dor" (BRAGA, 1991, p. 11). Ao expor a razão do choro, a protagonista também referiu-se ao passado e à causa que conduziu ela e a avó ao exílio:

Era a primeira vez que chorava desde que deixara a casa de seus maiores, desde aquela noite de infância em que os soldados haviam desligado os pés da avó, prendido o pai, levado as jóias. Julgava ainda poder ouvir os gritos de dor da avó por entre as gargalhadas dos militares. Pobres pés estropiados! Thinha chorado justamente por isso.

\footnotetext{
4 Do original: as regards the sexes, the male is by nature superior and the female inferior, the male ruler and the female subject. The courage of a man is shown in commanding, a woman's lies in obeying.

5 O Livro das Mutações, ou seja, o / Ching, em chinês 易经, é o mais antigo dos cinco clássicos confucionistas e a base da sabedoria chinesa, um conjunto de estudos que analisa o mundo e o homem.
} 
Um orgulho, essa avó de sapatinhos de cetim no pezinho de fada. Última coluna de mítica, venerável ancestralidade, despedaçada sem dó num impeto de mãos brutais. Sim, fora pelos pés da avó que então chorara. Aquilo era como profanar o templo, como desonrar os mortos (BRAGA, 1991, p. 11).

A superação desse valor ancestral da cultura chinesa era evidente no pensamento angustiante da protagonista. De certa forma, os pés atados simbolizam uma cultura da China tradicional, uma prática ancestral e, também, um aspecto que significa a opressão sobre as mulheres em uma sociedade patriarcal. Porém, naquela altura esse costume tradicional foi profanado pelos soldados japoneses. E, essa profanação, nas palavras de Dora Nunes Gago (2017, p. 12), "no fundo funciona como um prelúdio da violação que, posteriormente, terá talvez ocorrido no seu próprio corpo".

No entanto, os pés atados da avó, nos olhos da protagonista, simbolizavam "o longo e forçado destino da mulher. O mesmo destino que a tolhia, a angústia que nesse instante lhe subia à garganta" (BRAGA, 1991, p. 11). É verdade, na sociedade da China tradicional do sistema patriarcal, que o papel do homem é liderar, enquanto a esposa, filha e concubina e outras mulheres devem se comportar com toda a paciência, humildade e submissão para manifestarem os seus respeitos à soberania masculina. Verificamos que a avó dessa história era uma mulher que se submeteu à doutrina tradicional chinesa.

Nesse conto, a avó representa a China antiga com os valores culturais e religiosos do tempo passado. Para as mulheres na China antiga, apesar de os pés atados representarem o sofrimento físico e a restrição da liberdade, eram considerados como símbolo de uma posição social elevada. Por isso, mesmo vivendo na terra do exílio depois da invasão, não se integrou à sociedade nova. Como se vê na história, a avó tomou antigos preconceitos e não sabia falar cantonense, língua privilegiada da comunicação na terra do exílio, perdendo assim o acolhimento e a inclusão na comunidade circundante.

A avó não aceitou a distância entre a vida próspera do passado na China continental e a situação miserável no exilio de Macau. Esse autoencerramento, como observa Dora Nunes Gago (2017, p. 12): "desencadeia a inadaptação e o ostracismo". Ao mesmo tempo, o exilio também significa o fim de um passado, da China antiga.

Nesta consequência, verificamos que a avó do conto "A China fica ao lado" era uma mulher de imagem negativa. Porém, embora fosse uma mulher criticada pelas suas ideias antiquadas e pela sua vivência apenas no passado, foi uma mulher por qual a autora mostrou simpatia pelos seus sofrimentos.

\section{Mulher nova no caminho do despertar}

Este tipo de imagem feminina demonstra a imagem da mulher rebelde da ética feudal. É a representante das mulheres da nova era buscando o renascimento por meio do despertar da consciência. Lutam corajosamente contra a velha sociedade e as ideias antigas e realizam actividades antifeudais para que obtenham direitos e liberdades. São imagens positivas sob a escrita da autora. A protagonista "Ela" do conto "A China fica ao lado" é uma representante desta imagem da mulher nova no caminho do despertar.

No conto "A China fica ao lado", para a protagonista, nesse momento, "um sentimento de liberdade possuía-a inteira, uma dolorosa, opressiva liberdade" (BRAGA,1991, p. 10). Essa liberdade, não só vem do corpo (nesse caso o aborto), mas também representa a sua própria libertação contra as doutrinas tradicionais. Nesta sequência,

Um protesto cresceu-lhe nas entranhas,
fez-lhe sacudir a cabeça com força.
Não, não era a última derrota. Estava
ali por não ter morrido nem virado fan-
tasma. Os seus pés, soltos, poderiam
palmilhar todos os caminhos do mundo.
Poderia voltar à China ou ficar ao lado
da China. O principal era combater o
seu combate de mulher só e abusada. E
guardar o coração intacto. Para um dia.
Para uma verdade (BRAGA, 1991, p. 12).

Através da luta interna da protagonista, vemos que ela representou uma imagem da nova mulher no contexto social dominado pelos homens, em comparação com a avó que era uma mulher tradicional com pensamentos antigos. Em palavras mais simples, é como se representasse 
a mudança entre a China antiga - a avó - e a China nova - a neta. A autora concedeu a essa protagonista uma imagem muito positiva. Ocupou uma posição positiva por aspirar à liberdade e à dignidade. Em outras palavras, é uma figura feminina que não aceitou o destino que the coubera e foi afirmada pela autora. Além disso, ela mostrou a consciência de lutar contra a injustiça bem como o espírito de buscar a libertação das mulheres chinesas oprimidas ao longo do tempo:

E via-se a caminhar por uma estrada sem bermas, os braços alongados até ao infinito, levando consigo, triunfal, sem esforço, como se fossem penas de ave, toda a legião ancestral das ofendidas, de pés atados deslizando à flor da terra (BRAGA, 1991, p. 13).

Aos olhos da autora, os pés atados simbolizavam o longo e forçado destino da mulher, já anteriormente mencionado, mas a personagem principal, a neta, superou essa tradição e esse conformismo limitadores. No entanto, é importante ressaltar que, nesse conto, Maria Ondina Braga salienta que a emancipação verdadeira não é apenas a libertação dos pés atados, mas exige a independência e autonomia da mulher como um individuo. Caso contrário, segundo Adams (1995. p. 88), não seria capaz de se livrar do controlo ocidental, pois a fraqueza das mulheres de pés atados e a fraqueza da China ficam lado a lado.

\section{Mulher tradicional cheia de virtudes}

Maria Ondina Braga criou uma imagem nobre da mulher chinesa, imagem da mãe que possuiu as melhores virtudes comuns das mulheres chinesas tradicionais, tais como dirigente, forte, firme, econômica e corajosa. É uma imagem da mulher chinesa muito positiva e afirmada pela autora. A representante dessa imagem afirmativa é a personagem "avó" no conto "A Morta".

No conto "A morta", a protagonista Mei-Lai era uma professora de inglês no mesmo colégio que a narradora. É com a descrição do convite de Mei-Lai para passear no claustro em uma tarde sufocada de tufão que a história se inicia. Mei-Lai memorou e relatou a vida toda sobre a sua avó, que morreu em um dia de tufão:

A avó fora uma mulher notável que, apesar de pobre, criara dez filhos para a riqueza. Pequena, magra, activa, inteligente, mandara seis rapazes para a América, para a terra do oiro, à custa só das leiras de arroz por ela duramente trabalhadas de sol a sol. Quando o marido morreu, andava pejada do décimo filho. A viuvez, contudo, não a assustou: nada podia assustar uma mulher como ela. [...] o produto da venda, arrecadado no fundo da arca, destinava-se à viagem dos filhos. Durante vinte anos não teve mais do que duas cabaias de pano grosseiro. Os sapatos que a familia levava ao pagode nos dias de festa eram feitos por ela com palhas de arroz e pele de porco.

[...]

Depois, a velha não quis aceitar mais nada. Riqueza para ela não tinha sentido. [...] Era a satisfação de ter cumprido o seu dever de mãe (BRAGA, 1991, p. 74).

No excerto supracitado, podemos ver que, a velha, avó de Mei-Lai, é uma figura representativa da imagem de boa vida sob a cultura tradicional, possuindo as virtudes tipicamente tradicionais. Era diligente, pois trabalhou de sol a sol. Era também forte e firme, uma vez que não se assustou e não desistiu após a morte do seu marido. Era, ainda, poupadora e económica, visto que fazia os sapatos da familia com palhas de arroz e pele de porco. Isso, por outro lado, também mostrou que a avó de Mei-Lai era muito competente. Além dessas virtudes, a sua atitude em termos de riqueza trouxe uma impressão de que ela se tornou ausente de qualquer perturbação material supérflua.

Além de ser diligente e forte, a avó de Mei-Lai era ainda corajosa. Perante os soldados japoneses, um discurso da avó cheio de inteligência salvou a vida de todo o povoado, como se vê no conto:

Os soldados prendiam a torto e a direito, ameaçavam pegar fogo ao povoado. E foi então que a avó se ergueu na praça para falar às mulheres.

Mal começou a falar, desceu em torno um fundo silencia. O discurso feito com as veras da alma e mais ainda a sua humilde e patética figura, entre os soldados de armas aperradas, suspensos, e o povo inquieto, impressionaram uns e outros.

A avó pedia às mulheres que mostrassem a força da sua dor (BRAGA, 1991, p. 75). 
Durante a fuga para Macau, encontraram-se em um dia de tufão terrivel, e nessa situação dura, a avó mostrou a qualidade de firmeza, pois "A velha era a única que mantinha a força interior, que ia dando alma aos companheiros" (BRAGA,1991, p. 75). Assim, podemos saber que a avó era uma figura representativa da mulher tradicional. Ela simboliza os valores brilhantes e as qualidades melhores de uma mulher tradicional. Podemos sentir, também, o elogia que a autora mostrou pela inteligência, coragem, diligência e, ainda, firmeza da mulher chinesa.

\section{Mulher trágica sob a pressão da ética feudal}

No conto "Ódio de Raça", a protagonista Tai$\mathrm{Ku}$, a filha primeira do senhor rico, era uma filha com amor filial, cuidando do senhor rico, mas desculpando a luxúria do pai. Foi, portanto, uma personagem que esteve submetida aos valores culturais da China antiga, mas não tinha direito de manifestar as suas próprias opiniões:

Todas as manhãs, impassivel, Tai-Ku ia tomar a temperatura ao banho do pai. Os cabelos tinham-lhe embranquecido naquele mister. As chinelas de palha de arroz pisavam sem ruido o mosaico dos pátios. Primogénita, cumpria o dever filial sem indagar quem era a nova mulher, sem the querer mal, sem the interessar conhecê-la (BRAGA, 1991, p. 23).

Nesta história, Tai-Ku tinha um ódio obsessivo interior dos japoneses por causa da invasão à China e da ocupação japonesa da sua casa. Quando o seu pai tomou por concubina uma mulher japonesa, Tai-Ku, por motivo de vingança, fez um planejamento para matá-la. A mulher japonesa morreu, no entanto, seu pai, derrotado pela tristeza, ficou gravemente doente e seguiu-a, um pouco mais tarde, até o túmulo.

Tai-Ku, como era uma budista sincera, cumpriu as doutrinas da sua religião. Além disso, era considerada uma mulher tradicional chinesa, uma vez que, para o seu pai, Tai-Ku era obediente e cumpriu o dever filial; enquanto para a sua família toda, ela assumiu a responsabilidade de gerenciar as tarefas domésticas, tais como "verificou as despesas do dia, deu ordens para o dia seguinte" (BRAGA,1991, p. 25). Nessa consequência, pode se ver que a personagem principal Tai-Ku era uma mulher competente e diligente, mulher com as boas virtudes que uma mulher tradicional chinesa devia possuir.

Como é sabido, na sociedade feudal, para manter o interesse da familia patriarcal e de acordo com o principio "superioridade masculina e inferioridade feminina", a mulher tradicional chinesa devia seguir o padrão moral do confucionismo "três obediências e quatro virtudes", 6 padrão que conferia à mulher pela doutrina confucionista em termos de moralidade, comportamento e educação. As três obediências significam "obedecer ao pai antes do casamento, ao marido após o casamento, e ao filho em viuvez; enquanto as quatro virtudes abrangem moralidade, palavras adequadas, modéstia e diligência.

Nesse conto, a protagonista Tai-Ku pertenceu à primeira obediência acima mencionada, isto é, "obedecer ao pai antes do casamento", uma vez que ela não se casou. Enquanto as irmãs haviam partido uma a uma para casa dos maridos, Tai-Ku ficara. No entanto, sendo "primogénita, cumpria o dever filial sem indagar quem era a nova mulher" (BRAGA, 1991, p. 23).

Por essa passagem, podemos ver que a personagem feminina Tai-Ku se submeteu à doutrina confucionista, obedecendo ao seu pai e preocupando-se com a sua familia. Além disso, ela também possuia a virtude diligente. Foi uma mulher tipicamente tradicional. Essa valorização da lealdade à familia, ao clã e à casta é também uma dimensão da cultura oriental.

No entanto, o forte ódio pelos japoneses fez com que a protagonista Tai-Ku se tornasse uma mulher cheia de rancor, na medida em que os japoneses destruíram o seu lar e causaram indiretamente a morte da sua mãe. Tai-Ku transferiu esse rancor pelos japoneses para a mulher japonesa. Aos olhos de Tai-Ku,

\footnotetext{
6 As três obediências e as quatro virtudes são os códigos de conduta e moralidade para restringir as mulheres na sociedade feudal da China. As três obediências vêm de Yi Li, enquanto as quatro virtudes, de Zhou Li. Ambos pertencem aos Treze Clássicos Confucionistas.
} 
mesmo que os princípios da doutrina budista demandassem a bondade e, especialmente, o não matar, considerou a sua vingança um acto de justiça para "extirpar o mal":

a sua religião ensinava: não matar. Mas não mandava também extirpar o mal? E não representava a japonesa o pior de todos os males - a violência, a guerra... e aquele inferno dentro do seu peito? (BRAGA, 1991, p. 25).

O acto de vingança deu-lhe uma sensação de existência cumprida. Porém, acabou por destruir a essência familiar (neste caso o seu pai) e, pôr fim, à sua familia. Através da análise de toda a história, podemos saber que a autora Maira Ondina Braga, obviamente, não afirmou à personagem principal Tai-Ku em termos do seu acto de vingança. $\mathrm{Na}$ perspectiva da Maria Ondina Braga, a vingança do ódio pelos invasores japoneses não devia ser transferida para matar uma mulher japonesa inocente. Por isso, a autora deu ao conto um fim negativo no final.

Pelo exposto, Tai-Ku pagou o preço pelo acto de vingança, já que ela perdeu o seu pai. Por outro lado, o pai, senhor rico, também pagou um preço muito alto pelas suas ações ao tomar a japonesa como concubina. Partindo desse aspecto, parece que a autora tinha um bom conhecimento sobre as filosofias do Budismo, como a significação de "o mal se paga com o bem" demonstrado nesse conto. Aliás, a poligamia foi um vício na sociedade feudal da China. A autora criticou esse vício, pois o considerou uma luxúria e uma doença.

\section{Mulher sofrida da tristeza, pobreza e solidão}

No livro A China fica ao lado, quase todas as personagens femininas criadas por Maria Ondina Braga viveram em uma situação de tristeza, pobreza e solidão, só que as suas sensações surgiram por razões diferentes. De certa forma, as mulheres, tanto as intelectuais (neste caso, as professoras no colégio de Macau) como as refugiadas da camada social baixa da China continental mostraram uma imagem das mulheres com forte sensação de tristeza, pobreza e solidão.
No conto "Os Espelhos", Miss Carol, sendo pequena e magra, mestiça de mãe chinesa e pai inglês, e professora de Literatura Inglesa, é uma figura que possuía várias características estranhas aos olhos da narradora, como por exemplo: o seu quarto era forrado de espelhos. Além disso, a vida de Miss Carol não era conhecida por outras pessoas: "Eu perguntava a mim mesma se ela não teria familia, relações, um namorado. Nunca a via sair à noite ou ir ao cinema com amigos" (BRAGA, 1991, p. 17-18).

Parece que Miss Carol era uma pessoa misteriosa, tendo muitos segredos ou sofrimentos escondidos. O seu quarto coberto de espelhos traz ao leitor uma sensação de mistério. De facto, sobre a vida misteriosa de Miss Carol ainda se mostra o seguinte:

\begin{abstract}
E nunca uma chamada telefónica para a professora de Literatura Inglesa. Nunca para ela o anúncio da porteira: É voz de cavalheiro. Nem correio na bandeja do bengaleiro, afora os avisos da Congregação da Praia Grande com o seu carimbo em cruz. Nem visitas tão-pouco. $E$ todos os anos mais um espelho na parede do quarto (BRAGA, 1991, p. 18).
\end{abstract}

Esse aspecto de mistério, mais precisamente o mistério oriental, é, de facto, um tipo de exotismo frequentemente escrito pelos escritores ocidentais sobre o Oriente. E para a autora Maria Ondina Braga, a China é sem dúvida um país exótico, um país cheio de mistérios. E os mistérios, segundo Rogério Miguel Puga (2011, p. 558), "contribuem para a representação ficcional do exotismo testemunhado em Macau", onde aconteceram as histórias de A China fica ao lado.

Por outro lado, partindo da análise de toda a história, chegamos a conhecer que os espelhos provavelmente refletem o opressivo ambiente de habitação das mulheres que trabalham nesse colégio. Então, significa que Miss Carol tencionou sair dos limites de espaço, "para ela própria gozar a ilusão de dormir num grande quarto?" (BRAGA, 1991, p. 18).

Esses espelhos podiam também refletir a loucura da Miss Carol, na medida em que a narradora tinha a mesma preocupação: "E perguntava a mim mesma, aterrada, se, revestidas por completo as paredes de espelho, Miss Carol 
não começaria a espelhar o soalho e o tecto, imergindo na loucura" (BRAGA, 1991, p. 19). De facto, podemos ver que toda a história passa por um forte sentimento de tristeza, pobreza e solidão.

Os espelhos, bem como outras características de Miss Carol fizeram com que ela se tornasse uma personagem misteriosa, oferecendo várias dúvidas à narradora que causou na sua imaginação as possibilidades sobre Miss Carol. E a sensação misteriosa da narradora, também simbolizou o sentimento da autora Maria Ondina Braga sobre a imagem das mulheres chinesas contatadas no território de Macau. Os mistérios sempre tornaram a China um pais exótico. Isto é, de facto, uma atitude do Eu para com o Outro nos fenômenos de exotismo (PUGA, 2011, p. 256). Em outras palavras, também podemos dizer que o Outro é, muitas, vezes inacessivel.

\section{Mulher budista no coração e cristã pelo espírito}

Macau é um lugar onde as culturas chinesas e ocidentais se misturam. É um centro de intercâmbio cultural entre a China e o Ocidente. A obra de A China fica ao lado foi criada com base na experiência real de Maria Ondina Braga no território de Macau. Nesse contexto, pode se descobrir que muitos enredos da coexistência entre a cultura chinesa e a cultura ocidental surgiram nas histórias. A autora traz uma impressão ao leitor de que tinha muito interesse neste fenômeno, especialmente, no âmbito da convivência das diferentes religiões. Neste sentido, a autora criou uma figura "a senhora Tung" que servia para mostrar a cidade de Macau como local da coexistência das culturas e religiões. Foi uma imagem da mulher cujo espírito ficava vagando entre o Budismo e o Cristianismo.

No conto "Natal Chinês", a senhora Tung. cuja filha, a irmã Chen-Mou, era uma cristã que trabalhou no colégio do convento, mantém uma estátua do Menino Jesus, mas também da Deusa da Fecundidade no seu quarto, por tê-la dado filhos quando o seu marido se preparava para receber nova esposa.

Através da leitura do conto, sabemos que a senhora Tung, de facto, não era cristã, visto que o seu coração continuava apegado ao Budismo. Porém, para agradar à sua filha Chen-Mou, nomeava-se catecúmena e

vestira-se de gala para a festividade da meia-noite, tinha no quarto o Menino Jesus cercado de flores, e a alma transbordava-lhe de alegria como se cristã verdadeiramente fosse (BRAGA, 1991, p. 82).

A fim de fazer a sua filha feliz, a senhora Tung tinha o Menino Jesus no seu quarto, e colocou a Deusa da Fecundidade na gaveta. Mas a sua filha não era a favor de o fazer, para a sua filha, "o Menino Jesus entristecia, em cima da cómoda, por causa da deusa na gaveta" (BRAGA, 1991, p. 83). Isso quer dizer que a sua filha, Chen-Mou, de facto esperou que a senhora Tung tornar-se verdadeiramente uma cristã em vez de ser uma Budista no coração. No que diz respeito a isso, a narradora apetecia-se negar a declaração da sua filha, embora, no fim, isso não tenha se realizado.

As palavras da narradora no fim do conto ilustram a intenção e a ideia da autora Maria Ondina Braga. Na perspectiva da autora, não existem conflitos entre a religião Budista e a religião Cristã. Ambas as religiões estão em pé de igualdade e podem conviver na sociedade, especialmente, em Macau.

\section{Considerações finais}

Como uma escritora ocidental que nasceu e cresceu em Portugal, não era fácil para Maria Ondina Braga se livrar do imaginário coletivo social da sociedade europeia sobre a China e os chineses. Tal como refere a estudiosa chinesa Meng Hua (2001, p. 7): "qualquer indivíduo não consegue se apartar absolutamente da ideia colectiva, seja quão forte a sua consciência crítica", pois a sensibilidade dum escritor ou leitor à realidade estrangeira está estreitamente ligada ao imaginário coletivo social. A mesma linha de pensamento, é seguida por Dora Nunes Gago (2007, p. 63), "quando um indivíduo observa uma determinada realidade, o seu espirito encontra-se já preenchido por representações colectivas através das quais a apreende, produzindo significações". 
Nesta consequência, pode-se dizer que é justamente no seio do imaginário coletivo social que se formaram as imagens das mulheres chinesas transmitidas por Maria Ondina Braga. Através da leitura e da análise dos contos do livro A China fica ao lado, verificamos que a autora ficou muito fascinada pela cultura chinesa. Havia várias descrições dos costumes chineses como pés atados, ópio-fumante, tomar concubina, preferência pelo filho em detrimento da filha, o adivinho, a crença do Budismo o herbanário, a superstição e o Império. Esses aspectos são típicos olhares curiosos europeus sobre a China no imaginário coletivo ocidental.

Tudo isto mostrou que, para Maria Ondina Braga, a China era um país exótico cheio de mistérios orientais. Essas imagens da China e dos chineses estavam, de facto, ligadas aos estereótipos mostrados na literatura ocidental em relação à China. Em outras palavras, mesmo que a autora tenha experiência real na China, a sua sensibilidade à cultura chinesa estava estreitamente ligada ao imaginário europeu, observando a China de uma visão ocidental. Tal como se refere Mo Xishi:

Estas imagens têm significados simbólicos de sofrimento, fraqueza, enterramento e apego à cultura antiga. São um resultado típico de observar o Oriente do ponto de vista ocidental, especialmente a imagem simulada feminizada da China (MO, 2007, p. 41).

Além disso, como um membro da comunidade europeia, quando descreveu as imagens de mulheres chinesas, Maria Ondina Braga também não se livrou dos estereótipos tradicionais ocidentais apresentados na literatura europeia. Talvez aportasse em Macau "a sua específica [bagagem cultural] adquirida num imaginário social específico, produtor de estereótipos" (GAGO, 2013, p. 37).

Por outro lado, como Álvaro Manuel Machado e Daniel-Henri Pageaux (1988, p. 59) referem: quando uma sociedade observa e imagina o "Outro", realiza-se, simultaneamente, a autoobservação e a reflexão. Na verdade, quando Maria Ondina Braga descreveu a tristeza e a solidão das mulheres chinesas, nomeadamente as que saíram da terra natal (neste caso, a China continental) para o exílio de Macau, a autora mostrou a sua forte simpatia pelos seus sofrimentos, e ao mesmo tempo, expressou a sua própria tristeza de deixar a sua terra natal e expôs a sua solidão enquanto trabalhava em Macau.

Em palavras de Daniel-Henri Pageaux, há geralmente quatro atitudes de observador em relação à cultura estrangeira e que regem a representação do Outro, Então, no que se refere a Maria Ondina Braga, verificamos que essa pertencia à terceira atitude, isto é, "a realidade cultural estrangeira é tida por positiva e situa-se no interior de uma cultura igualmente considerada de maneira positiva" (MACHADO; PAGEAUX, 1988, p. 74). Verifica-se uma admiração mútua e trocas bilaterais. É verdade, Maria Ondina Braga sempre demonstrou muito interesse e fascinação na cultura chinesa, pois, para ela, tudo era exótico na China. Ela observou a cultura chinesa com um coração curioso e ao mesmo tempo mostrou simpatia pelos sofrimentos de mulheres chinesas e afirmou os seus esforços em libertação.

\section{Referências}

ARISTOTLE. Politics, I, 5 (1254b). Translated and with an introduction by Carnes Lord. Chicago: University of Chicago Press, 1984

BEAUVOIR, Simone de. O Segundo Sexo. Tradução: Tao Tiezhu. Beijing: Chinese book publishing house, 1998. t. I e II.

BEZERRA, Luciana da Silva. A escrita itinerante de Maria Ondina Braga: autobiografia, ficção e memória. Tese (Doutorado) - Universidade Federal do Rio de Janeiro, Rio de Janeiro, 2011.

BRAGA, Maria Ondina. A China fica ao lado. Macau: Instituto Cultural de Macau, 1991

BROOKSHAW, David Rowan. Perceptions of China in Modern Portuguese Literature. Border Gates. [S. l.]: The Edwin Mellen Press, 2002.

GAGO, Dora Nunes. Entre pés de lótus e bambus, configurações da China nos contos de Maria Ondina Braga e Fernanda Dias. Colóquio Letras, n. 184, p.3544, set./dez. 2013.

GAGO, Dora Nunes. Figurações Femininas nas Obras de Deolinda da Conceição, Maria Ondina Braga e Fernanda Dias: Os Árduos Caminhos do Exílio e da Emancipação. Revista de Cultura, Macau, p. 6-17, 2017. 
GAGO, Dora Nunes. No espelho da memória: Macau, lugar mítico de (re)construção da identidade na obra de Maria Ondina Braga. Acta Scientiarum Language and Culture, Maringá, v. 38, n. 1, p. 1-9, jan./mar. 2016 https://doi.org/10.4025/actascilangcult.v38i1.26921.

LUO, Ting; WANG, Fang. A aceitação e a Influência de Beauvoir na China. Contemporary Foreign Literature, v. 4, p.123, 2004.

MACHADO, Álvaro Manuel; PAGEAUX, Daniel-Henri. Da Literatura Comparada à Teoria da Literatura. [S. L.] Edições 70, 1998.

MENG, Hua. 比较文学形象学. IImagologia da Literatura Comparada]. Beijing: Peking University Press, 2001.

MO, Xishi. 二十世纪澳门土生葡人著作研究. [Estudo dos romances da Literatura Macaense do século XX]. Dissertação (Mestrado) - East China Nornal University, Shanghai, 2007.

MOURA, Jean-Marc. L'imagologie littéraire: essai de mise au point historique et critique. Revue e Littérature Comparée, [s. L.], v. 3. p. 271, 1992

MOURA, Jean-Marc. L'imagologie littéraire: essai de mise au point historique et critique, 1992. Tradução Meng Hua. In: COMPARATIVE LITERATURE IN CHINA. Shanghai: Shanghai Foreign Language Education Press, 1995. v. 1 e 2.

MOURA, Jean-Marc. L'imagologie littéraire: essai de mise au point historique et critique. Revue e Littérature Comparée, [s. L.], v.3. p. 277-287, 1992.

OLIVEIRA, Silvia. Análise Pedagógica-Didáctica dos Contos "A China Fica ao Lado" de Maria Ondina Braga. Dissertação (Mestrado) - Universidade Católica Portuguesa, Lisboa, 2011.

PAGEAUX, Daniel-Henri. Imagologia da Literatura Comparada,1994. Tradução: MENG Hu. In: COMPARATIVE LITERATURE IN CHINA. Shanghai: Shanghai Foreign Language Education Press, 1998. v. 4.

SILVA, Maria Araújo da. A experiência da viagem na obra de Maria Ondina Braga:

objectos de busca, cruzamentos e desencontros. Navegações, Porto Alegre, v. 6, n. 2, p.188-195, jul./ dez. 2013

SMITH, Nicholas D. Plato and Aristotle on the Nature of Women. Journal of the History of Philosophy, [s. l.], v. 21, n. 4, p. 467-478, 1983. https://doi.org/10.1353/ hph.1983.0090.

\section{Ming Xin}

Doutoranda em Literatura e Estudos Interculturais (Português) pela Universidade de Macau (UM, Macau, China).

\section{Endereço para correspondência}

Ming Xin
Universidade de Macau

Avenida da Universidade, Taipa

Macau, China 